\title{
ELABORATION OF THE METHOD OF ASSESSMENT OF THE SEVERITY DEGREE OF COMPANIES CRISIS
}

\author{
Vladimir Nusinov \\ Department of Accounting, Taxation, Public Management and Administration \\ State Institution of Higher Education "Kryvyi Rih National University" \\ 11 Vitalyy Matusevych str., Kryvyi Rih, Ukraine, 50027 \\ vladimir.nusinov@gmail.com
}

\begin{abstract}
The analysis of scientific literature allowed us to establish the absence of unified approach to the assessment of severity of the company crisis. The definition of the term "crisis severity degree" was specified and its five-level gradation was offered, namely: absence of the crisis, its light, middle, hard and critical severity degree. From our point of view, this gradation is intuitively comprehensive for all groups of stakeholders, involved in the process of anti-crisis management and most fully characterizes the condition of the company in the aspect of possible anti-crisis arrangements. The three-level hierarchic structure of the types of crisis of the company was offered. The use of hierarchic structure favors the better understanding of the causes of crisis, its results and possible ways out of crisis. The aforesaid is attained by separation of the different types of crisis then the components of these types of crisis are separated and so on. At the same time at each step it is necessary to concentrate attention on understanding of the current element, temporarily abstracting from all other components. At such analysis the whole complexity and severity of the company crisis can be understood. The methodology of determination of the severity degree of the company crisis was elaborated for each level of hierarchy. The diagnostics of the severity degree of the company crisis of the higher level of hierarchy must be realized using the matrix of pair comparison and the severity degrees of crisis must be integrated for each its component based on the laws of economic logic. The matrix of comparison of the severity degrees of the company crisis is recommended to be formed by comparison of two parameters of assessment of the crisis of the low level of hierarchy that allows range the comparable objects in two-dimensional space. The severity degree of financial crisis of the company is offered to be determined taking into account the probability of its bankruptcy and of economic, social and ecological one - by the comparison of the current values of assessment parameters with their base values. The values of pre-crisis period are recommended to be used as the base ones. The approbation of offered methodology of assessment of the severity degree of the company crisis was realized.
\end{abstract}

Keywords: crisis, types of crisis, severity degree of crisis, assessment, diagnostics, probability of bankruptcy, scale of assessment of the severity degree of crisis, matrix of comparison of the severity degrees of crisis.

\section{Introduction}

The functioning of the market system is attended with crisis phenomena. It is impossible to imagine the development of the modern economy without economic upturns and recessions as the result of which the economic stability is broken and economic subjects are in certain imbalance. The development of the crisis in Ukrainian companies is not an exception.

The starting point of construction of the model of anti-crisis management is a diagnostics of crisis condition, which essence in most generalized form can be reduced to the definition of series of its qualitative characteristics.

\section{Analysis of the literary data and statement of the problem}

For constructing the model of anti-crisis management of the company it is important to diagnose the presence or absence of crisis. For this aim it is important, first of all, to understand the essence of the notion "crisis".

Having studied the most spread definition of the category "crisis", used in scientific terminology, the presence of large number of formulations that define its essence was established that is an acknowledgment of complexity and variability in understanding of this category. It was determined, that the authors characterize crisis as an event [1-4]; unforeseen but not unexpected event [5]; wide-ranging, unpredictable event [6-8]; situation [9, 10]; emergency [11]; pile of factors [12]; phenomenon [13]; unexpected incident [14]; "crucial moment" or "turning point" [15]. 
It must be noted, that the problem of assessment of the severity degree of crisis and determination of the measures of its elimination in Ukrainian companies is extremely important and not sufficiently elaborated.

\section{Aim and tasks of research}

The aim of the work is elaboration of the methodology of assessment of the severity degree of company crisis.

For attaining this aim the following tasks were set:

1. To study the essence of the notion "crisis severity degree" and to specify its definition.

2. To elaborate the hierarchy of parameters of assessment of the severity degree of companies crisis.

3. To elaborate the methodology of aggregation of the parameters of assessment of the severity degree of companies crisis.

4. To evaluate the crisis severity degree of the results of activity on the example of Ukrainian companies.

\section{Materials and methods of research}

We agree with scientists, who find expedient to range crisis by its severity degree [16-20]. The essence of offered author methodologies can be reduced to the use of the different total scores that characterize the presence of crisis condition and interval breaking of the whole diapason of possible values according to the separated degrees of crisis.

At the same time it must be noted, that for today there is no definition of the essence of this notion. So, we offer to understand the crisis severity degree as the comparative value, established on the base of the totality of symptoms, causes and factors of crisis and characterizing the company condition for the evaluated period of time by the presence or absence of crisis, intensity of its passing and possible results.

\section{Results of the studies}

From our point of view, the types of company crisis are financial, economic, social, ecologic and corporative. All variety of other crises is their subtypes.

Financial crisis is characterized by the possible change of juridical status of the company, particularly, its bankruptcy.

Economic, social and ecological crises are characterized by inadmissible deviations of correspondent qualitative and quantitative results of the activity of company from their model values.

Corporative crisis is autonomous and does not directly depend on the other types of company crisis. It is characterized by the possible loss of the owner's corporative rights and does not directly depend on the results of activity of the company.

The crisis types and correspondingly the parameters that assessment of their severity degree is based on, form the hierarchy of the structure of company crisis types (Fig. 1).

We offer to diagnose the crisis severity degree separately for each type and to form the conclusion about the severity degree of the company crisis as a whole by the combination of the results of assessment of each type of crisis for the separate parameters upwards for each level of hierarchy.

It is offered to range the severity degrees of company crisis as following:

- critical degree of crisis (CD);

- hard degree of crisis (HD);

- middle degree of crisis (MD);

- light degree of crisis (LD);

- absence of crisis (AC).

This classification of the crisis severity degrees, from our point of view, characterizes the possible company conditions in the aspect of possible anti-crisis arrangement more fully.

Let's consider the process of integration of the results of assessment of the company crisis in detail. 


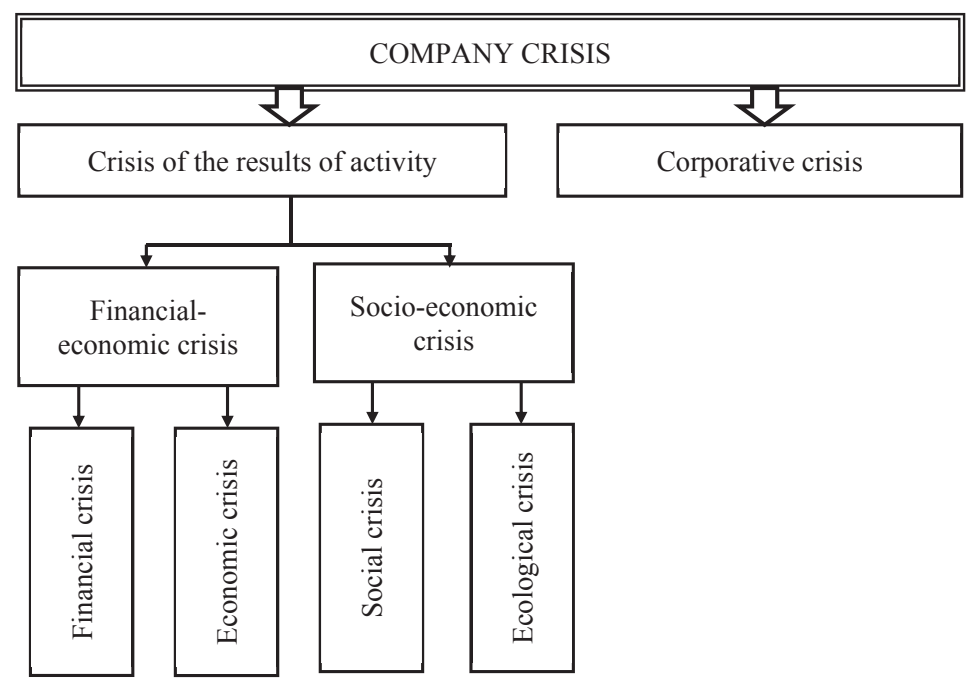

Fig. 1. Hierarchic structure of the company crisis types

We agree with T. Saati that at creation of the method of analysis of hierarchies the strict logic analysis is the single reliable method of the solution of complicated problems [21].

The worst crisis severity degree for the company is a critical one that is diagnosed at the bankruptcy of the company with further liquidation, loss of rights by majority owners, coercive stop of the business and loss of the company assets without its formal liquidation.

We think that at the diagnostics of the critical degree of company crisis at any hierarchy level for any type of crisis, the general conclusion about the critical degree of company crisis in whole must be done, because it does not matter what was its cause (bankruptcy, liquidation, annulations of permission for emission of polluting substances, raider occupation or other).

We think that at evaluation of the complex parameter of assessment of the severity degree of company crisis, the matrix of comparison of the crisis severity degrees is the most convenient form of presentation of calculations.

Let's consider the order of assessment of the crisis severity degree of the results of activity of the company.

Financial crisis is the most essential for company for today. Since this type of crisis is characterized with the probability of bankruptcy of the company, the severity degree of this type of crisis depends on did the company come in the bankruptcy procedure or no, or is measured by the probability of this event.

The following approaches are used for the diagnostics of the probability of bankruptcy of the company:

1) point system of assessment (M. Tamari,Argenti);

2) one-factor, discriminant analysis (V. Biver, P. Wiber);

3) multiple-factor discriminant analysis (E. Altman, A. Tereschenko, G. Springate, R. Raffler, R. Lis).

From our point of view, the multiple-factor disrciminant models are most exact, because they synchronously take into account the influence of many factors. At the same time their reliability is proved by the statistical tests.

The most known model of diagnostics of the probability of company bankruptcy is the five-factor one, elaborated by the American economist E. Altman on the base of multiple-factor discriminant analysis $\mathrm{H}(1)$ :

$$
Z=1,2 X_{1}+1,4 X_{2}+3,3 X_{3}+0,6 X_{4}+X_{5}
$$

where $\mathrm{X}_{1}$ - working assets/summary assets; $\mathrm{X}_{2}$ - retained earnings/summary assets; $\mathrm{X}_{3}$ - operating profit/summary assets; $X_{4}$-summary assets/general duties; $X_{5}$-sales proceeds/summary assets. 
Key of interpretation for the E. Altman's model:

$\mathrm{Z}<1,8$ - very high probability of bankruptcy (critical condition);

$1,8<\mathrm{Z}<2,7$ - high probability (hard crisis degree);

$2,7<Z<2,9$ - possible bankruptcy (light crisis degree);

$\mathrm{Z}>2,9$ - low probability (absence of crisis).

It must be also noted, that E. Altman's model can be applied for the assessment of severity degree of financial crisis.

We offer to determine the crisis severity degree for each given parameter by the finding of Kotz index that characterizes the ratio of the values of parameters in the current period to the base ones.

For assessment of the crisis severity degree for the parameters that characterize the presence or absence of economic, social, ecological and corporative crisis of the company by the expert method, the following scale is defined and accepted for the use (2):

$$
\begin{gathered}
\text { Kotz } \leq 0-\text { critical degree of crisis; } \\
\text { Kotz } \leq 0,5-\text { hard degree of crisis; } \\
0,5<\text { Kotz } \leq 0,75-\text { middle degree of crisis; } \\
0,75<\text { Kotz } \leq 1-\text { light degree of crisis; } \\
\text { Kotz }>1-\text { absence of crisis. }
\end{gathered}
$$

The critical severity degree of the crisis is diagnosed at the loss of the rights by majority owners, coercive stop of the business, bankruptcy.

We think that the severity degree of economic crisis of the company must be diagnosed on the base of change of the main parameters that characterize the interests of its majority owners. And they are interested in the parameters that characterize the value of company for potential buyers (cost of the company) and its internal value (own capital).

According to the cited conception, the actual values of parameters correlate with the base ones (parameters of pre-crisis period) and the correspondent coefficients of assessment of the crisis severity degree are calculated (Kotz).

At the first stage of diagnostics the coefficient of assessment of the crisis severity degree is determined for the parameter of own capital (Coc) (3):

$$
\mathrm{Coc}=\mathrm{Oct} / \mathrm{OC} \text { pre, }
$$

where OCt, OC pre - values of the own capital in assessed moment of time $t$ and correspondingly in the moment before crisis, hrn.

It must be taken into account, that the value of own capital of the companies in crisis condition is often negative. In such case the value of own capital is prognosticated for the next year. If even the prognosticated value of own capital is negative, the conclusion about the crisis condition of the company is made. In other case the hard degree of crisis is diagnosed.

The next one at the diagnostics is the coefficient of assessment of the crisis severity degree, calculated for the parameter of company cost (Cs) (4):

$$
\mathrm{Cs}=\frac{\mathrm{St}}{\mathrm{Spre}},
$$

where St, Spre - the company cost in assessed moment of time $t$ and correspondingly in the moment before crisis, hrn.

The cost of the company is determined by the profitable method. If the cost of the company is negative, it is prognosticated for the next year. If even the prognosticated value of own capital is negative, the conclusion about the crisis condition of the company is made. In other case the hard degree of crisis is diagnosed. 
The severity degree of economic crisis is diagnosed on the base of conclusion about the severity degree of the company crisis using the matrix method (Table 1). At the same time the critical degree of the crisis severity is not considered because, as it was noted above, its diagnostics at any stage of assessment excludes the variability of final results.

Table 1

Matrix of assessment of the severity degree of economic crisis on the base of comparison of the crisis severity degrees for the parameters of company cost and the own capital

\begin{tabular}{|c|c|c|c|c|}
\hline \multirow{2}{*}{$\begin{array}{l}\text { Crisis severity degree for } \\
\text { the parameter of company cost }\end{array}$} & \multicolumn{4}{|c|}{$\begin{array}{l}\text { Crisis severity degree for } \\
\text { the parameter of own capital }\end{array}$} \\
\hline & HD & MD & LD & $\mathbf{A C}$ \\
\hline HD & HD & HD & MD & LD \\
\hline MD & HD & MD & MD & LD \\
\hline LD & MD & MD & LD & LD \\
\hline $\mathrm{AC}$ & LD & LD & LD & $\mathrm{AC}$ \\
\hline
\end{tabular}

For the formation of generalizing conclusion about the severity degree of financial-economic crisis, let's construct the matrix of pair comparison of the degrees of financial and economic crisis (Table 2).

Table 2

Matrix of the assessment of the severity degree of financial-economic crisis on the base of pair comparison of the severity degrees of financial and economic crisis

\begin{tabular}{|c|c|c|c|c|}
\hline \multirow{2}{*}{ Severity degree of economic crisis } & \multicolumn{4}{|c|}{ Severity degree of financial crisis } \\
\hline & HD & MD & LD & $\mathbf{A C}$ \\
\hline HD & HD & HD & MD & LD \\
\hline MD & HD & MD & MD & LD \\
\hline $\mathrm{LD}$ & MD & MD & LD & LD \\
\hline $\mathrm{AC}$ & LD & LD & LD & $\mathrm{AC}$ \\
\hline
\end{tabular}

The severity degree of socio-economic crisis is not considered in the aspect of majority shareholders because their interests to the dynamics of these parameters are secondary.

Let's consider the order of assessment of the severity degree of ecological crisis.

In the process of activity the industrial companies throw out the harmful substances in atmosphere, spill the waste water in water reservoirs, place wastes in the land that leads to the growth of ecological expenditures: ecological tax, reparation of ecological damage.

The parameters, used at the assessment of ecological crisis in the companies:

- volume of the emissions of polluting substances in atmosphere (e);

- volume of the waste water $\left(\mathrm{m}^{3}\right)$.

Coefficient of assessment of the severity degree of ecological crisis $(\mathrm{Cec})$ is determined as following (5):

$$
\mathrm{Cec}=\frac{\mathrm{Ve}_{\mathrm{ATb}}}{\mathrm{Ve}_{\mathrm{ATt}}} \times \mathrm{k}_{\mathrm{AT}}+\frac{\mathrm{Vw}_{\mathrm{wt}}}{\mathrm{Vw}_{\mathrm{Bt}}} \times \mathrm{k}_{\mathrm{w}},
$$


where $\mathrm{Ve}_{\mathrm{ATt}}, \mathrm{Ve}_{\mathrm{ATb}}$ - volume of the emissions of polluting substances in atmosphere in the base and current period $\mathrm{t}$, respectively, $\mathrm{T} ; \mathrm{Vw}_{\mathrm{Bt}}, \mathrm{Vw}_{\mathrm{wt}}$ - volume of the spillage of waste water in the water reservoirs, $\mathrm{m}^{3} ; \mathrm{k}_{\mathrm{AT}}, \mathrm{k}_{\mathrm{w}}$ - coefficients of the weight of the emission of polluting substances in atmosphere and water reservoirs respectively.

Since the indices of the emission of polluting substances are heterogenic, the weight coefficients are used for their reduction to the generalizing parameter. Thus, for the companies of mining industry and metallurgy we accepted $\mathrm{k}_{\mathrm{AT}}=0,7, \mathrm{k}_{\mathrm{w}}=0,3$.

At insufficient volumes of the emissions that don not lead to the outflow of money, it is not expedient to calculate the severity degree of ecological crisis.

The scale (2) is used for the assessment of the severity degree of ecological crisis. The critical degree at the assessment of ecological crisis is diagnosed at the stop of permissions for the emission of polluting substances that leads to the stop of company.

Then let's consider the social crisis. We think that the parameters of social crisis must be based on the interests of such groups of stake holders as the workers of company that are mainly interested in volume and timeliness of received salary, additional social package, stable work.

Let's determine the order of assessment of the severity degree of social crisis. The following parameters are used for that:

- mean month salary of one worker;

- socially oriented expenditures;

- number of dismissed workers.

The parameters, used for the severity degree of social crisis, are heterogenic, that is why the correspondent weight coefficients are used for their reduction to the generalizing parameter, analogously to the assessment of the severity degree of ecological crisis.

The degree of socio-ecological crisis is assessed on the base of the following matrix (Table 3):

Table 3

Matrix of the assessment of the severity degree of socio-ecological crisis on the base of pair comparison of the severity degrees of social and economic crisis

\begin{tabular}{ccccc}
\hline Severity degree of social crisis & \multicolumn{2}{c}{ Severity degree of ecological crisis } \\
& HD & MD & LD & MC \\
\hline HD & HD & HD & MD & LD \\
LD & MD & MD & LD & LD \\
AC & MD & LD & AC
\end{tabular}

Having determined the severity degrees of the financial-economic and socio-ecological crisis, let's diagnose the severity degree of the crisis of the company activity results. The following matrix is constructed for it (Table 4).

The parameter of the severity degree of financial-economic crisis is a priority one.

Then let's consider the order of assessment of the severity degree of corporative crisis.

Above in the article was noted, that the corporative crisis is autonomous and does not directly depend on the other types of company crises. Since this crisis does not depend on the parameters of company activity, it is logically to realize its diagnostics on the base of revelation of the series of factors and events.

The light severity degree of corporative crisis is diagnosed in the company in two cases:

1. At the initial stage of the development of corporative conflict at the primary designation of its symptoms.

2. At the stage of its end at presence of the residual phenomena of corporative crisis. 
The middle severity degree of corporative crisis is diagnosed at the evident manifestation of corporative conflict, its escalation. At that the subject and sides of the conflict can be distinctly defined. The fact of physical occupation of the company is absent. As to the legal proceedings, the files are not yet transmitted to the court or it is always won by the present owner.

The hard severity degree of the company corporative crisis is characterized by the aggravation of conflict situation, attempts of the physical occupation of the company, beginning of legal proceedings. At the same time the evident preference of the present owner is absent, the probability of winning is insufficient.

The critical severity degree of corporative crisis is diagnosed at the loss of the present owner in legal proceedings, physical occupation of the company.

The severity degree of the company crisis is determined by the pair comparison of the results of company activity and corporative crisis (Table 5).

Table 4

Matrix of the assessment of the severity degree of the crisis of company activity results by the pair comparison of the severity degrees of socio-ecological and financial-economic crisis

\begin{tabular}{ccccc}
\hline Severity degree of socio-ecological crisis & \multicolumn{3}{c}{ Severity degree of financial-economic crisis } \\
\hline HD & HD & MD & LD & AC \\
MD & HD & MD & MD & LD \\
LD & HD & MD & LD & AC \\
AC & HD & MD & LD & AC
\end{tabular}

Table 5

Matrix of the assessment of the severity degree of company crisis on the base of pair comparison of the severity degrees of crisis of the results of its activity and corporative crisis

Severity degree of the crisis of the results of company activity

Severity degree of corporative crisis

\begin{tabular}{ccccccc} 
Severity degree of the crisis of the results of company activity & HD & MD & LD & AC \\
\hline HD & HD & HD & HD & HD \\
MD & HD & MD & MD & MD & LD \\
LD & HD & MD & MD & LD & AC
\end{tabular}

The severity degree of the company crisis is offered to be defined for the worst variant. We think that the high parameters of the company activity do not exclude the appearance of corporative conflict or raider occupation. From the other side, the corporative crisis can be absent in the company in the procedure of bankruptcy.

\section{Discussion of the results}

At this stage of development of Ukrainian ore processing plants we must note the absence of corporative crisis in them. That is why the crisis is characterized by the results of their activity.

The severity degree of the crisis of the activity results of the ore processing plants (OPP) of Kryvyi Rih city for 2014-2015 was assessed by the offered methodology. The results of assessment are presented in the Table 6. 
Table 6

Assessment of the severity degree of the crisis of the activity results of the ore processing plants of Kryvyi Rih city for 2014-2015

\begin{tabular}{|c|c|c|c|}
\hline Parameters of the severity degree & 2014 & 2015 & Qualitative changes \\
\hline \multicolumn{4}{|c|}{ PSC “Inguletsky OPP” } \\
\hline Financial-economic crisis & HD & HD & Without changes \\
\hline Socio-ecological crisis & MD & HD & Worsening \\
\hline Crisis of the activity results & HD & HD & Without changes \\
\hline \multicolumn{4}{|c|}{ PSC “NOTHERN OPP” } \\
\hline Financial-economic crisis & MD & MD & Without changes \\
\hline Socio-ecological crisis & MD & HD & Worsening \\
\hline Crisis of the activity results & MD & MD & Without changes \\
\hline \multicolumn{4}{|c|}{ PSC “CENTRAL OPP” } \\
\hline Financial-economic crisis & LD & LD & Without changes \\
\hline Socio-ecological crisis & MD & HD & Worsening \\
\hline Crisis of the activity results & LD & MD & Worsening \\
\hline \multicolumn{4}{|c|}{ PSC “SOUTHERN OPP” } \\
\hline Financial-economic crisis & $\mathrm{AC}$ & LD & Worsening \\
\hline Socio-ecological crisis & $\mathrm{MD}$ & $\mathrm{CD} / \mathrm{HD}$ & Worsening \\
\hline Crisis of the activity results & $\mathrm{LD}$ & $\mathrm{CD} / \mathrm{MD}$ & Worsening \\
\hline
\end{tabular}

Thus, the crisis of the activity results was diagnosed for studied plants in 2014-2015. The tendency of severity degree testifies to the intensification of crisis.

\section{Conclusions}

As the result of research:

1. The analysis of scientific literature allowed us to establish the absence of the unified approach to the assessment of the company crisis, because the different classification signs are used: stages, degrees, phases, scales, depth of the crisis and so on. We agree with the authors who assess the severity degree of the company crisis. At the same time these authors do not define the essence of this notion, so this definition was specified.

2. The absence of complexity in the study of assessment of the severity degree of the company crisis was established taking into account the features of their present economic activity. The hierarchy of the parameters of assessment of the severity degree of the company crisis was elaborated.

3. The approach to the assessment of the severity degree of the company crisis as to the complicated system of its subdominant types using the matrix of pair comparison of the severity degree of each type of crisis (financial, economic, social ecological and corporative) was offered.

4. The approbation of offered methodology of assessment of the crisis severity degree on the example of Ukrainian company was realized. The severity degrees of crisis of the activity results of ore processing plants of Kryvyi Rih city for 2014-2015 were defined.

Taking into account the elaborated methodology of assessment of the severity degree of the company crisis, the aim of further research is logically the study and improvement of anti-crisis management of the companies at the modern stage of their development. 


\section{References}

[1] Davies, G., Chun, R., Vinhas da Silva, R., Roper, S. (2003). Corporate Reputation and Competitiveness. New York: Routledge, 29. Available at: http://samples.sainsburysebooks.co.uk/9781136863288_ sample_888543.pdf

[2] MacNeil, W., Topping, K. (2007). Crisis management in schools: Evidence-based prevention. Journal of Educational Inquiry, 7 (1), 64-94.

[3] Ross, D. How Crisis Communication Plans Work. HowStuffWorks MONEY. Available at: http://communication.howstuffworks.com/how-crisis-communication-plans-work.htm

[4] Wang, W.-T., Belardo, S. (2005). Strategic Integration: A Knowledge Management Approach to Crisis Management. Proceedings of the 38th Annual Hawaii International Conference on System Sciences. doi: 10.1109/hicss.2005.559

[5] Coombs, W. T. (2011). Ongoing Crisis Communication: Planning, Managing, and Responding. UK: SAGE Publications, 231. Available at: https://books.google.com.ua/books?id=r6K0pRwbNn0C\&print$\mathrm{sec}=$ frontcover $\& \mathrm{hl}=\mathrm{uk} \# \mathrm{v}=$ onepage $\& \mathrm{q} \& \mathrm{f}=$ false

[6] Baker, G. F. (2001). Race and Reputation: Restoring Image Beyond the Crisis. Handbook of Public Relations, 513-520. doi:10.4135/9781452220727.n43

[7] Barton, L. (1993). Crisis in organizations: Managing and communicating in the Heat of Chaos. Cincinnati. Ohio: South-Western, 256.

[8] Mitroff, I. I., Shrivastava, P., Udwadia, W. A. (1987). Effective crisis management. The Academy of Management Perspective, 1 (4), 283-292.

[9] Bernstein, J. (2016). The 10 Steps of Crisis Communications. Bernstein Crisis Management. Available at: http://www.bernsteincrisismanagement.com/the-10-steps-of-crisis-communications/

[10] Ömer, G. (2008). Definition and management of international crises. Center for strategic research Republic of Turkey Ministry of Foreign Affairs. Available at: http://sam.gov.tr/wp-content/uploads/2012/02/ OmerIsyar.pdf

[11] Lagadec, P. (1996). Un nouveau champ de responsabilité pour les dirigeants. Revue française de gestion, 100-109. Available at: http://www.patricklagadec.net/fr/pdf/revue_francaise_gestion_1996.pdf

[12] Roux-Dufort, C., Lalonde, C. (2013). Editorial: Exploring the Theoretical Foundations of Crisis Management. Journal of Contingencies and Crisis Management, 21 (1), 1-3. doi:10.1111/1468-5973.12014

[13] Fearn-Banks, K. (2007). Crisis Communications: A Casebook Approach. London, 402. doi:10.4324/9780203936696

[14] Kozlowski, C. (2010). Crisis Management. Crisis Control Newsletter from RQA, Inc., UO110 (1). Available at: https://www.rqa-inc.com/newsletters/Catlin_US_U0110.pdf

[15] Brown, D. C. G. (2014). Crisis Management in a Governance and Public Administration Context: An International Perspective. Canadian Association for Programs in Public Policy and Administration Third Annual Research Conference Kingston. Ontario. Available at: http://cappa.ca/images/resources/ DCGBrown $\% 20-\% 20$ Crisis $\% 20$ management $\% 20$ from $\% 20$ an $\% 20$ international $\% 20$ perspective $\% 20-\% 20$ CAPPA\%202014-05-21.pdf

[16] Burkova, L. A. (2015). Ocinka zaxodiv shhodo podolannya kryzy na girnycho-zbagachuvalnyx kombinatax. Efektyvna ekonomika, 1. Available at: http://www.economy.nayka.com.ua/?op=1\&z=4113

[17] Ishhenko, M. I. (2014). Teoriya ocinky finansovo-ekonomichnyh rezultativ diyalnosti promyslovyh pidpryyemstv. Kryvyj Rig: Vyd. R. A. Kozlov, 422.

[18] Lapickij, A. V. (2013). Krizis organizacii: sushhnost' i klassifikacionnyj. Sovremennaja jekonomika: problemy i reshenija, 8 (44), 72-89.

[19] Lukashenko, E. V. (2003). Diagnostika krizisnogo sostojanija kompanii v sovremennyh uslovijah hozjajstvovanija. Ekonomika: problemy teoriyi ta praktyky, 136-142.

[20] Mishhuk Ye. V. (2008). Osoblyvosti diagnostyky krytychnoyi sytuaciyi na girnycho-zbagachuvalnyh pidpryyemstvah. Ekonomika: problemy teoriyi ta praktyky, 241 (4), 854-860.

[21] Tomas L. Saati. (2015). Ob izmerenii neosjazaemogo. Podhod k otnositel'nym izmerenijam na osnove glavnogo sobstvennogo vektora matricy parnyh sravnenij. Cloud of Science, 2 (1). 